\title{
From tin- to antimony-based yellow opacifiers in the early Islamic Egyptian glazes: Regional influences and ruling dynasties
}

\author{
${ }^{1}$ Elena Salinas, ${ }^{1}$ Trinitat Pradell, ${ }^{2,}{ }^{3}$ Moujan Matin, ${ }^{3}$ Michael S. Tite \\ ${ }^{1}$ Physics Department and Barcelona Research Centre in Multiscale Science and \\ Engineering, Universitat Politècnica de Catalunya, Campus Diagonal Besòs, Av. \\ Eduard Maristany, 10-14, 08019 Barcelona, Spain \\ ${ }^{2}$ Wolfson College, Linton Road, Oxford OX2 6UD \\ ${ }^{3}$ Research Laboratory for Archaeology and the History of Art, Dyson Perrins Building, \\ South Parks Road, Oxford OX1 3QY, UK
}

\begin{abstract}
A representative selection of early Islamic glazed ceramics from Egypt, with yellow and/or green as major colours and spanning the period from $8^{\text {th }}$ to $11^{\text {th }}$ centuries has been studied. Following the production of Coptic Glazed Ware in $8^{\text {th }}$ century, in which lead stannate was used to produce an opaque yellow glaze side by side with brown and green transparent lead glazes, the lead stannate opaque yellow appears to have been lost in Egypt by the second half of the $9^{\text {th }}$ century when new shapes were produced consequence of the Abbasid Iraqi influence. However, by the $10^{\text {th }}$ century, polychrome glazed ceramics were being produced in the Fustat region using lead antimonate in the production of yellow, amber and green glazes which were applied side by side. At the same time, tin oxide began to be used for the production of opaque white and turquoise glazes. It is suggested that the rediscovery of lead antimonate was a result of experimental firings of available minerals, such as stibnite or a galena with stibnite impurities. Finally, with the Fatimid conquest of Egypt in 969 AD and the foundation of Cairo as the dynasty capital, the tradition for producing ceramics with yellow and green decoration over a white background spread from Ifriqiya (Tunisia) to Egypt. However, in Ifriqiya, the glazes were transparent and a whitened clay body provided the background whereas, in Egypt, lead antimonate was used for the yellow, and tin oxide for the white glaze which provided the background. From Egypt, the latter glaze technology spread to Tunisia, and from there to other Mediterranean regions.

In conclusion, it is argued that the political and historic events in Egypt and the wider Islamic world provided the main driving force for the observed changes in both ceramic style and glaze technology.
\end{abstract}

KEYWORDS: Egypt, Ifriqiya (Tunisia), Abbasid and Fatimid dynasties, Glazed ceramics, opacifiers, Lead stannate, Lead antimonate, Tin oxide. 


\section{Introduction}

Much has been written about early glazed ceramics in Egypt from $8^{\text {th }}$ to the $11^{\text {th }}$ centuries. This has been mainly about assemblages found at Fustat and kept in Museums and private collections, with the reports concentrating on typological and decorative studies. Although there has been some study of the body fabrics, information on the glazes and glaze technology has been scarce. During this period, there has been a succession of Umayyad, Abbasid and Fatimid caliphates involving also changes in the centre of power, in aesthetic considerations and in regional influences. Ceramic fabrics can be regarded as being directly related to the ceramic production centres in that clays and sands rarely travel between regions. In contrast, the materials and methods used in the production of glazes provide information about the regional exchanges associated with the introduction and spread of new aesthetic fashions and new technologies. Thus, in the context of glazes, among other developments, there was the emergence of tinbased yellow and white opaque glazes as well antimony-based yellow opaque gazes, the introduction of new pigments, colourants and methods of glaze application, and the arrival of lustre decoration. The aim of the current study of the Egyptian glazed ceramics of the period is to understand the regional influences and exchanges, and their link to the political power.

Following the hypothesis by Watson (2014) that the production of Islamic fine glazed ceramics started in Egypt and the Levant in the $8^{\text {th }}$ century, with the emergence of the so- called Coptic Glazed Ware (CGW) (Rodziewicz 1978), rather than in Mesopotamia in $9^{\text {th }}$ century, Tite et al. (2015) and Matin et al. (2018) have examined a wide range of Islamic glazed ceramics from Egypt and the Levant through to Mesopotamia and beyond spanning the period from $8^{\text {th }}-10^{\text {th }}$ centuries. These authors have established that, in the ceramics produced in Egypt and the Levant, lead stannate was used to opacify very high lead $(>60 \mathrm{wt} \% \mathrm{PbO}+<2 \mathrm{wt} \%$ alkali) yellow glazes and tin oxide to opacify high lead-alkali (40-50wt\% $\mathrm{PbO}+4-5 \mathrm{wt} \%$ alkali) white glazes. Subsequently, these two tin opacified glaze technologies spread to Mesopotamia in $9^{\text {th }}$ century where white tin oxide opacified glazes of the alkali-lead type $(10-12 \mathrm{wt} \%$ alkali $+2-5 \mathrm{wt} \% \mathrm{PbO})$ became dominant in the production cobalt-blue and lustre decorated ceramics.

From $9^{\text {th }}$ century Mesopotamia, lead stannate opacified yellow glazes of the very high lead type spread eastwards into Northern Iran and Central Asia (i. e., Nishapur, Merv and Samarqand) in $10^{\text {th }}$ century. At the same time, tin oxide white glazes of the leadalkali type (typically $30 \mathrm{wt} \% \mathrm{PbO}+10 \mathrm{wt} \%$ alkali) spread both eastward into Northern Iran and Central Asia, and westwards beyond the Levant and Egypt into Islamic Spain (late $9^{\text {th }}$ - early $10^{\text {th }}$ centuries), North Africa (late $10^{\text {th }}$ century - early $11^{\text {th }}$ century), and ultimately northern Spain, southern France and Italy (13 ${ }^{\text {th }}$ century). In addition, polychrome glazed ceramics (PGW) both of and related to the so-called Fayyumi ware (Scanlon 1993) whose decoration included opaque amber and yellow glazes were produced in Egypt during $10^{\text {th }}$ century and beyond. However, preliminary measurements by Tite et al. (2015) suggested that these yellow glazes were opacified with lead antimonate rather than the lead stannate previously used in the $8^{\text {th }}$ century. Finally, very recently a publication about the excavations at the walls of Cairo (Monchamp 2018) has provided a collection of polychrome over opaque white ware and 
yellow glazed ware from the Fatimid period (FGW) (last decades of the $10^{\text {th }}$ century$12^{\text {th }}$ century), which have not yet been analysed.

In the present paper, a representative selection from the Kaczmarczyk collection (Tite, 2010)of early Islamic glazed ceramics from Egypt spanning the period from $8^{\text {th }}$ to $11^{\text {th }}$ centuries has been studied using a combination of optical microscopy (OM), scanning electron microscopy with energy dispersive analysis (SEM-EDS). The selection is based on a previous study of over 400 samples (Tite, 2010) from the collection kept in the Research Laboratory of Archaeology and the History of Art (Oxford University); the surface analysis of the different color glazes helped to select those containing both tin and antimony yellow particles. The first aim of the paper is to clarify the evolution of methods of production of the opaque yellows in Egypt from its beginnings with the production of $\mathrm{CGW}$, through the production of PGW ware, to the production of Fatimid glazed ware (FGW) after the Fatimid conquest of Egypt in 969 AD. The second aim is to link these changes in glaze technology to historical and political events both in Egypt and the wider Islamic world. Of particular interest is the consideration of, first, why there was the emergence of lead antimonate in place of lead stannate for the production of yellow glazes in Egypt and how the former opacifier was rediscovered, and second, how the white tin-opacified glaze technology spread through North Africa and beyond.

This proposed research is enabled by the recent publications by the Institut français $d^{\prime}$ 'archéologie orientale of early $9^{\text {th }}$ and $10^{\text {th }}$ century ceramic assemblages from its excavations at Istabl 'Antar (Gayraud and Vallauri, 2017) including not yet analysed ceramics equivalent to our PGW, and of late $10^{\text {th }}$ to $16^{\text {th }}$ century ceramics from excavations at the walls of Cairo, including not yet analysed ceramics equivalent in form and decoration to our FGW ware (Monchamp 2018). As a result of the application of stratigraphic methods at these excavations, it is now possible to provide an approximate chronology for glazed ceramic assemblages from earlier archaeological surveys and excavations, such as those found in the kilns excavated at Bahnasa (Féhérváry et al 2006) and, in particular, to our selection of shards from the Kaczmarczyk collection.

\section{Glazed ceramic samples}

A total of fourteen glazed sherds were selected from the Kaczmarczyk collection to cover the range of Egyptian glazed wares with yellow covering most or part of the surface of the glazes spanning the $8^{\text {th }}-11^{\text {th }}$ centuries, two (ALX202, ALX66) of which had been previously analysed by SEM-EDS (Tite et al., 2015, Matin et al, 2018). Regarding the form of these ceramics, one sherd is from a jar (ALX51), but the remainder are all from bowls.

The sherds have been divided into three primary groups (i.e., Group I, II and III), and each group is further sub-divided into two types according to the form and decoration inferred for the associated ceramics (i.e., Types I-1 and I-2, and Types II-1, II-2 and Types III-1 and III-2). Figure 1 shows a selection of the samples characteristic of each group. 
$<$ Figure $1>$

One of the primary problems encountered in the study of Egyptian glazed ceramics is the variety of names, in many cases inaccurate, given to them. Thus, the earliest glazed ceramics (our Group I - Type I-1) have been variously described as Coptic Glazed Wares (Rodziewicz 1978; Watson 2014; Whitcomb 1989), Aswan Glazed Wares (Adams 1986), and Slip-Painted Early Lead-Glazed Wares (Scanlon 1998), although they are known to be opaque glazed rather than slip-painted; while Type I-2 has been described as "kaolinitique glaçurée" (Gayraud and Vallauri 2017). Similarly, the most characteristic polychrome Egyptian glazed ceramics (our Group II) have been variously described as Early Fayyumi (Scanlon 1993) and Opacified U-Shaped Splash Wares (Williams 2013) for our Type II-1; and as Fatimid Fayyumi-I (Scanlon 1993), Fayyumi Wares (Whitcomb 1989) and also as Five-colour Fayyumi style (Adams 1986) for our Type II-2. Finally, the yellow glazes from the Fatimid period (our Type III-2) are also called lemon-yellow glazed wares (Monchamp 2018).

Because the Fustat ceramics from the Kaczmarcyk collection came from old excavations, we have used the recent publications based on stratigraphic excavations to provide a more accurate chronology for the different groups that we have identified. Hence, in Group I which we will call kaolinitic glazed ware (KGW), Type I-1 (CGW) is the earliest, dating to late $7^{\text {th }}-8^{\text {th }}$ centuries (Watson 2014) and early $9^{\text {th }}$ century (Gayraud and Vallauri 2017). This is followed by Type I-2 which dates to second half of the $9^{\text {th }}$ century (Gayraud and Vallauri 2017), both types being produced during the Abbasid period and production seeming not to have been continued afterwards. In Group II which we will call polychrome glazed ware (PGW), Type II-1 also dates to second half $9^{\text {th }}$ century (Gayraud and Vallauri 2017). Type II-2 is dated to a much expanded period, 850-1150 AD (Scanlon 1993) or 850-1200 AD (Williams 2013), which starts in the Abbasid period but continues into the Fatimid period. However, there was a typological evolution which allows us to distinguish between both periods (Monchamp 2018), with the samples studied in the current paper exhibiting the earliest vessel shapes and therefore, being dated to the Abbasid period. Finally, Group III, which we will call Fatimid polychrome glazed ware (FGW), is dated to the late $10^{\text {th }}$ and $11^{\text {th }}$ centuries and includes Type III-1, polychrome over opaque white ware and, Type III-2, Fatimid yellow glazed ware (FYG) (Monchamp 2018). The characteristics of the above Groups and Types, together with their associated samples are given in Table 1.

$<$ Table 1 $>$

\subsection{Group I (KGW)}

Group I (KGW) is characterised by the use of a pink firing, kaolinitic clay known as Aswan fabric (Yousef 1996; Baioumy, Ismael 2014; Ownby et al. 2017).

Type I-1 (ALX202) is a shallow bowl with a flat base and a wall curved outward to a thin-lipped rim recalling pre-Islamic shapes $(\mathrm{CGW})$. The decoration of this type of ceramic is opaque polychrome with up to four colours applied side-by-side (yellow, green, brown, white) and with an opaque white glaze underside. 
Type I-2 (ALX203, ALX205), whose form and decoration represent a transition toward Type II-1, are deep bowls with a flat bases, sharp edges, and flattened and rounded flange rims, related to the arrival of Mesopotamian Abbasid and Chinese influences. The decoration is transparent polychrome with three colours side-by-side (yellow/amber, green, brown) and with touches of glaze on the underside.

\subsection{Group II (PGW)}

Group II (PGW) is characterised by the use of a buff firing calcareous clay. The shapes are deep bowls with ring feet and hemispherical profiles.

Type II-1 (ALX63) is a transition type which coexists with the earlier Coptic Glazed Ware and also with Iraqi lustreware imports (Williams 2015). The sherd is from a small bowl with a slightly out-curving rim which is characteristic of early Abbasid shapes, as found at Raqqa (François and Shaddoud 2013) and Yavneh-Yam (Taxel, 2014). The decoration is bichrome with overglaze green on a white opacified background and with a green opaque monochrome underside.

Type II-2 (ALX51, ALX65, ALX146, ALX152, ALX154) are bowls with high ring feet and undeveloped rims which have been broadly copied in the $10^{\text {th }}$ century Abbasid world such as at Nishapur (Watson 2004). The exception (ALX51) is a jar with a flat or slightly concave base, probably a globular body, a funnel neck and a straight rim. The decoration is opaque polychrome with adjacent radial or spoked bands or streaks of glaze in a variety of colours, sometimes as many as five (yellow/amber, green, brown, turquoise and white). The underside is monochrome transparent. This type of decoration continued into the Fatimid period with an evolution of the shapes (everted rims) (Monchamp 2018).

\subsection{Group III (FGW)}

Group III (FGW) is also characterised by the use of a buff firing calcareous clay. Both types are deep bowls with ring feet, curved bodies and flat everted rims which are the most common feature of the Fatimid glazed table ware (Monchamp 2018).

Type III-1 (ALX142) The decoration, which is again applied to both sides includes transparent polychrome yellow and green dots and stripes on opaque white glaze.

Type III-2 (ALX231, ALX66, ALX342, ALX135) The decoration, which is sometimes applied to both sides, includes polychrome with opaque yellow and green on opaque white, and with the yellow covering large areas of the object.

\section{Analytical techniques}

Polished sections through the glazes and into the bodies of the sherds were prepared. The polished sections were examined at the Universitat Politècnica de Catalunya (Barcelona) both in reflected light with an Optical Microscope (OM), and in a crossbeam workstation (Zeiss Neon 40) equipped with Scanning Electron Microscopy (SEM) GEMINI (Shottky FE) column with attached EDS (INCAPentaFETx3 detector, $30 \mathrm{~mm}^{2}$, ATW2 window, resolution $123 \mathrm{eV}$ at the $\mathrm{Mn} \mathrm{K \alpha}$ line energy), operated at 20 $\mathrm{kV}$ acceleration voltage with $1.1 \mathrm{~nm}$ lateral resolution, 20nA current and $120 \mathrm{~s}$ measuring 
time. The glaze and body microstructures were studied and recorded in backscatter mode (BSE) in which the different phases present could be distinguished on the basis of their atomic number contrast.

Chemical compositions of the bodies were determined by analysing a minimum of two areas, about $3 \mathrm{~mm} \times 2 \mathrm{~mm}$. Because of the porosity of the bodies, the analyses were normalised to $100 \mathrm{wt} \%$, and then averaged. For the glazes, the areas analysed were somewhat smaller, and as far as possible, were chosen to avoid areas of weathered glaze and areas near to the glaze-body interface; the results were again averaged. A selection of the non-plastic inclusions within the bodies, and opacifiers and other particles in the glazes were also analysed. An EDS elemental microanalysis system calibrated with oxide, mineral and glass standards was used to determine the microstructure and composition of the glazes (Geller Microanalytical Laboratory. MA. USA). Totals determined between $55 \%$ and $65 \%$ for the ceramic bodies and between $97 \%$ and $100.5 \%$ for the glazes. Polished cross sections of the ceramics and glazes, coated with a sputtered carbon layer $(<20 \mu \mathrm{m}$ thick), were measured. Typical detection limits are $0.1 \%$ for $\mathrm{Na}, \mathrm{Mg}, \mathrm{Al}, \mathrm{P}, \mathrm{K}, \mathrm{Ca}, \mathrm{Ti}, \mathrm{Mn}$ and $\mathrm{Fe}, 0.2$ for $\mathrm{Si}$ and $\mathrm{Cu}, 0.3$ for $\mathrm{Sn}$ and $\mathrm{Sb}$ and 0.4 for $\mathrm{Pb}$. Back-scattered Electron (BSE) images of the microstructures were obtained at $20 \mathrm{kV}$ acceleration voltage.

\section{Results}

The chemical compositions of the bodies are given in Table 2, and those of the glazes of Groups I, II and III are given in Table 3, 4 and 5 respectively.

$<$ Table 2>

\subsection{Bodies}

The pink coloured Group I bodies are characterised by high alumina contents (23-26 $\mathrm{wt} \% \mathrm{Al}_{2} \mathrm{O}_{3}$ ), significant iron oxide contents (4.0-4.5 wt\% FeO) (Fig. 2A) and abundant inclusions, including argillaceous rocks, rare grains of amphibole and potassium feldspars (Fig. 3A), These bodies are therefore consistent with the use of kaolinitic clay from the Aswan region, and the analyses (Table 2) with those found by other authors (Waksman et al 2017).

In contrast, the buff coloured Group II and III bodies are produced using calcareous marl clays (16-25 wt\% $\mathrm{CaO}+2-4 \mathrm{wt} \% \mathrm{MgO})$, containing lower alumina contents (10$14 \mathrm{wt} \% \mathrm{Al}_{2} \mathrm{O}_{3}$ ) but slightly higher iron oxide contents (5-8 wt \% FeO) (Fig. 2A), and with abundant inclusions of quartz and feldspar (Fig. 3B). The analyses (Table 2) are consistent with those corresponding to the calcareous pastes from Egypt analysed by other authors (Waksman et al 2017).

$<$ Fig. 2>

$<$ Fig. 3 $>$

\subsection{Group I (KGW) Glazes}


The Group I glazes are essentially of the very high lead type (Table 3 ) in that the lead contents of all the glazes are about $60 \mathrm{wt} \% \mathrm{PbO}$ and the alkali contents are less than 1 $w t \% \mathrm{Na}_{2} \mathrm{O}+\mathrm{K}_{2} \mathrm{O}$. All the glazes contain significant alumina contents (4-5 wt $\% \mathrm{Al}_{2} \mathrm{O}_{3}$ ). Some of the alumina content could be the result of interaction between the glaze and alumina rich body during firing. However, it seems probably that much of the alumina is the result of adding clay to the glaze slurry in order to keep the lead and silica particles in suspension, to increase the plasticity of the suspension, and to improve the binding between the glaze powder and the body (Tite et al. 1998). Group I glazes have a composition different from the other two groups which are more alike (Fig. 2B). The various colour glazes (yellow, green and also brown) are applied side by side over the surface of the ceramic.

\section{$<$ Table 3>}

The yellow glazes contain approaching $2 \mathrm{wt} \% \mathrm{SnO}_{2}$, and as observed previously (Tite et al. 2015; Matin et al. 2018), the ALX202 glaze (Type I-1) contains lead stannate particles which result in its opaque yellow colour (Fig. 4 A, B). In contrast, neither lead stannate or tin oxide particles were detected in the Type I-2 yellow glaze (ALX203, ALX205), (Fig. 4 C, D), the tin oxide apparently having been dissolved in the glaze, possibly as a result of higher temperatures being used in firing the glaze. As a result, the Type I-2 yellow glazes are not opaque but transparent, and the yellow colour is due to the presence of about $1 \mathrm{wt} \% \mathrm{FeO}$.

The green glazes, which are coloured by copper dissolved in the glaze (1.0-3.5 wt $\%$ $\mathrm{CuO}$ ), are further distinguished by their higher lime (about $2 \mathrm{wt} \% \mathrm{CaO}$ ) and iron oxide $(1-2 \mathrm{wt} \% \mathrm{FeO})$ contents, as compared to the other colours. The brown glaze (ALX203) is coloured by manganese dissolved in the glaze $(0.8 \mathrm{wt} \% \mathrm{MnO})$. Although none of the green and brown glazes contain tin-based particles, some $\mathrm{SnO}_{2}$ was still detected as a result of the analyses being obtained in areas relatively close to the yellow area.

$<$ Fig. 4 $>$

\subsection{Group II (PGW) Glazes}

All Group II coloured glazes are of the high lead-alkali type (Table 4) (40-60 wt $\% \mathrm{PbO}$ $+2-6 \mathrm{wt} \%$ alkali), with the exception of the ALX65 glaze which has a lower lead content $(25-45 \mathrm{wt} \% \mathrm{PbO})$ and a higher alkali content $\left(7-10 \mathrm{wt} \% \mathrm{Na}_{2} \mathrm{O}+\mathrm{K}_{2} \mathrm{O}\right)$. These glazes show a reasonably good correlation between lead oxide and alumina, and between alumina and alkalis (Fig. 2B). This is most probably due to the dissolution of clay/sand in the glazes during firing. In fact all the glazes show the presence of large particles of undissolved sodium-calcium pyroxenes $(\mathrm{Ca}, \mathrm{Na}) \mathrm{AlSi}_{2} \mathrm{O}_{6}$ and feldspars.

$<$ Table 4>

The chronologically earlier group Type II-1 (ALX63) has a green glaze, coloured by dissolved copper $(1.2-2.5 \mathrm{wt} \% \mathrm{CuO})$ and opacified with lead antimonate particles $(0.2-$ $\left.0.6 \mathrm{wt} \% \mathrm{Sb}_{2} \mathrm{O}_{3}: \mathrm{PbO} / \mathrm{Sb}_{2} \mathrm{O}_{3}=60-80\right)$ which was applied over a white opaque glaze (3.3 $\mathrm{wt} \% \mathrm{SnO}_{2}$ ). This ceramic type has strong similarities (shape, decoration and colours) with contemporary Iraqi glazed wares. 
The main group Type II-2 (ALX51, ALX65, ALX146, ALX152, ALX154) may include as many as five different glaze colours (yellow or amber, green, turquoise, white and brown) which are applied side by side forming colour bands occupying the whole surface of the ceramic (Fig. 1 and Fig. 5A, B).

The amber and yellow glazes are coloured and opacified by lead antimonate particles (Fig. 5C, D, E, F) together with higher amounts of dissolved iron as compared to the other glaze colours. The antimony oxide contents are in the range 1.0-1.7 $\mathrm{wt} \% \mathrm{Sb}_{2} \mathrm{O}_{3}$ $\left(\mathrm{PbO} / \mathrm{Sb}_{2} \mathrm{O}_{3}=30-60\right)$ for the amber glazes and 0.2-0.5 wt $\% \mathrm{Sb}_{2} \mathrm{O}_{3}\left(\mathrm{PbO} / \mathrm{Sb}_{2} \mathrm{O}_{3}=100-240\right)$ for the yellow. The iron oxide contents vary from 2.4-2.8 $\mathrm{wt} \% \mathrm{FeO}$ for the amber glazes, and 1.3-2.3 wt\% FeO for the yellow glazes.

The lead antimonate particles appear well crystallised showing polyhedral shapes (Fig. $5 \mathrm{C}, \mathrm{D}, \mathrm{E}, \mathrm{F})$. They have a cubic structure (Fd-3m crystallographic group) known as pyrochlore and a theoretical composition $\mathrm{Pb}_{2} \mathrm{Sb}_{2} \mathrm{O}_{7}$ which incorporates small amounts other metals. In the present case, mainly iron, titanium and calcium which are incorporated from the glaze (typically between $0.1-0.4$ atomic $\mathrm{Fe}, 0.1-1.0$ atomic $\mathrm{Ti}$, 0.2-1.0 atomic $\mathrm{Ca}$ ), and which stabilise the pyrochlore structure (Molina et al 2014). Tin is only rarely incorporated into the lead antimonate particles because the colours containing tin do not normally contain antimony and vice-versa.

The green glazes are coloured by dissolved copper $(0.9-1.3 \mathrm{wt} \% \mathrm{CuO})$ together with lead antimonate particles $\left(0.2-0.9 \mathrm{wt} \% \mathrm{Sb}_{2} \mathrm{O}_{3}: \mathrm{PbO} / \mathrm{Sb}_{2} \mathrm{O}_{3}=60-240\right)$ which result in opaque glazes (ALX146, ALX152) (Fig. 5G).

Turquoise glazes, which are opacified by tin oxide particles (Fig. $5 \mathrm{H})\left(5.7 \mathrm{wt} \% \mathrm{SnO}_{2}\right.$ : $\left.\mathrm{PbO} / \mathrm{SnO}_{2}=7-9\right)$, are also coloured by dissolved copper $(0.7-1.6 \mathrm{wt} \% \mathrm{CuO})$. The white glazes are opacified with tin oxide particles (3-6 wt $\left.\% \mathrm{SnO}_{2}: \mathrm{PbO} / \mathrm{SnO}_{2}=4-20\right)$, and the brown glazes are coloured by dissolved manganese (1.5-4.1 wt\% MnO) (Fig. 5A, B).

$<$ Fig. 5 $>$

\subsection{Group III (FPG) Glazes}

All Group III coloured glazes are also of the high lead-alkali type (Table 5) (40-60 wt \% $\mathrm{PbO}+2-6 \mathrm{wt} \%$ alkali) and similar in composition to those used in the Group II glazes (Fig. 2B).

\section{$<$ Table 5>}

Type III-1 (ALX142) is characterised by the application of decorative patterns of transparent yellow and green glaze on top of a white glaze opacified by tin oxide (2.7$3.4 \mathrm{wt} \% \mathrm{SnO}_{2}$ ) which covers the whole surface of the object. The transparent yellow stripes are coloured by dissolved iron $(1.9 \mathrm{wt} \% \mathrm{FeO})$, and the green dots by dissolved copper $(1.9 \mathrm{wt} \% \mathrm{CuO})$. The yellow and green glazes contain $1.0 \mathrm{wt} \%$ and $2.1 \mathrm{wt} \%$ $\mathrm{SnO}_{2}$ respectively which is most probably due the underlying white glazes.

The main group Type III-2 (FYG) (ALX231, ALX66, ALX342, ALX135) is characterised by the application of a yellow glaze above and covering most of the white glaze and the application of green decorative patterns (Fig. 6A, B, F). 
The yellow glaze is coloured and opacified by lead antimonate particles (Fig. 6, B, C, $\mathrm{D}, \mathrm{E})$ together with dissolved iron. The antimony oxide contents are in the range $0.8-$ $1.5 \mathrm{wt} \% \mathrm{Sb}_{2} \mathrm{O}_{3}\left(\mathrm{PbO} / \mathrm{Sb}_{2} \mathrm{O}_{3}=30-60\right)$ and the iron oxide contents vary from $1.5-2.3 \mathrm{wt} \%$ FeO. Again the lead antimonate particles are well crystallised with polyhedral shapes (Fig. 6 D, E), and incorporate small amounts of iron, titanium and calcium. Tin is also incorporated into the lead antimonate particles placed close to the white glaze which contains tin oxide particles.

The underlying tin oxide opacified white glazes contain between 5.2 and $7.3 \mathrm{wt} \% \mathrm{SnO}_{2}$, present as cassiterite particles (Fig.6 G, H). As the green and yellow glazes are applied over the white glaze, the tin oxide observed in some of green glazes $(0.2$ or $5.1 \mathrm{wt} \%$ $\left.\mathrm{SnO}_{2}\right)$ and of the yellow glazes $\left(0.3-3.2 \mathrm{wt} \% \mathrm{SnO}_{2}\right)$ is again most probably due to the underlying white glaze (Fig. 6 F, G, H).

The green glazes are coloured by dissolved copper by itself (0.4-2.8 wt $\% \mathrm{CuO})$, although it is not uncommon to observe lead antimonate particles in the ALX231 and ALX66 glazes which contain $0.4 \mathrm{wt} \%$ and $0.6 \mathrm{wt} \% \mathrm{Sb}_{2} \mathrm{O}_{3}$ respectively, and this is probably due respectively to the underlying and adjacent yellow glaze.

$<$ Fig. 6 $>$

\section{Discussion}

Group I (KGW) corresponds to a different production centre to that of the other two groups. The clay used is kaolinitic comparable to those found in the south of Egypt, near to the Aswan region, and is known to have been used at Coptic centres related to the production of the Late Roman tableware tradition. In fact, the Coptic/Byzantine vessel shapes and painted decorations continued to be used in the production of early Islamic Egyptian glazed ware (Fig. 1) (Watson 2014; Williams 2015). Consequently, either the clay or, much more probably, the objects were transported from the south to the Fustat region. In this context, trade of table ware from Aswan to Alexandria between the $5^{\text {th }}$ and the $8^{\text {th }}$ centuries has been documented (Ballet et al. 1991) and, in particular during the Umayyad period, to Istabl 'Antar (Gayraud and Treglia 2016). Although the vessel shape and clay recall the earlier tableware tradition, the application of glaze during early Islamic times shows the introduction of a new technology, glazing probably being initiated in Egypt during the Umayyad and subsequent Abbasid rule (Watson 2014, Moujan et al 2018). The first productions are those using of lead stannate for the production of opaque yellow glazes (Type I-1, CGW - ALX202) (Fig. 4 A, B) with the glazes being in up to three different colours, transparent green and brown, and opaque yellow, which were applied side by side (Tite et al 2015, Moujan et al 2018).

Although Coptic Glazed Ware was also being produced in other parts of Egypt and in the Levant (Rodziewicz 1978; Whitcomb 1989), but as yet, the only analytical data are for a sherd found at Madaba in the Levant, dated to $7^{\text {th }}-8^{\text {th }}$ century, which has a calcareous clay body but again a very high lead yellow glaze opacified with lead stannate (Matin et al. 2018). 
In the second half of the $9^{\text {th }}$ century (Type I-2), tableware shapes changed, with a clear influence from $T$ 'ang glazed wares, as similarly happened in other regions of the Abbasid empire (e.g., Baghdad and Samarra), with the characteristic features being the low foot, hemispherical profile, everted/spilled rim and the splashed decoration (Fig. 1). These wares continued to be produced using a kaolinitic clay together with the same very high lead glaze recipe. However, although the yellow glaze has the same composition, neither lead stannate nor tin oxide particles are found (Fig. 4 C, D), and therefore, the yellow/amber glazes are transparent. The reason for this is yet to be understood, but in view of the same compositions, there must have been difficulties with the firing.

Group II (PGW) represents a fully established Islamic regional tradition with production probably being located in the Fustat region in the north where the clays of the calcareous type are found (Waksman 2017). Compared to the preceding Group I production, there have been changes in body type, shape (Fig. 1), colours, pigments, decorations, glaze application technique (Fig. 5), and glaze technology, these changes being associated with stronger Islamic influences from the Abbasid world as well as Chinese influences. As suggested by Mason and Tite (1997, 52), these developments could have been as a result of the movement of potters from Abbasid Iraq to establish new ceramic production centres at Fustat (Shovelton 2018).

Type II- 1 which is dated to the second half of the $9^{\text {th }}$ century is a transitional type which coexists with the earlier Coptic and also with Iraqi lustreware (Williams 2015). The ceramic analysed belongs to a foot-ring type with slightly out-curving rim, but the same type of vessels are also documented in other parts of Egypt, such as the island of Elephantine in the Nile by Aswan (Ownby et al. 2017), and Istabl 'Antar (Gayraud \& Vallauri 2017). The sample studied shows the, as yet, earliest recorded use in Egypt of both lead antimonate in the green glaze and tin oxide in the white glaze.

This type shows a clear Abbasid influence not only with regard to the shapes of the ceramics, but also with the extended use of tin oxide to produce opaque white glazes over which green, blue or brown decorations are applied, similar to those applied to Chinese ceramics which were produced using white firing clays.

However, the main ceramic type associated with this second stage of production is Type II-2 (Fayyumi type 1 ware), which is dated in the $10^{\text {th }}$ century. The production of this type of ceramic has recently been documented in Fustat (Sheehan 2010) and also in middle Egypt at Bahnasa which is $160 \mathrm{~km}$ south south-west of Cairo in the west side of the Nile (Féhérvari 2000). Our ceramics are dishes with hemispherical shapes and footrings which are not as fully developed compared to later productions. The bodies were produced using calcareous clays (Fig. 2), and the glazes were of the high lead-alkali type. Glazes in up to five different colours were applied side by side (Fig. 5A), as during the previous stage, but they now form long radial strips. Lead antimonate was added as an opacifier in the amber glazes (1.0-1.7 $\mathrm{wt} \% \mathrm{Sb}_{2} \mathrm{O}_{3}$ ) (Fig.5 C, D, E), in green glazes $\left(0.8-0.9 \mathrm{wt} \% \mathrm{Sb}_{2} \mathrm{O}_{3}\right)$ (Fig. $\left.5 \mathrm{G}\right)$, and with a lower antimony content, in the yellow glazes $\left(0.2-0.5 \mathrm{wt} \% \mathrm{Sb}_{2} \mathrm{O}_{3}\right)$. In addition tin oxide was used to opacify white and turquoise glazes (Fig 5. H). 
The third stage, which is dated in the late $10^{\text {th }}$ and $11^{\text {th }}$ centuries (Monchamp 2018), is associated with the production of Group III (FGW) ceramics, and represents a change with respect to the previous stage, not in the materials used (i.e, clay, glazes and pigments) but in the method of production (i.e., colours and style of decorations) (Fig. 6). As discussed below, this change is due to influence from Fatimid North Africa (Ben Amara et al 2005, Salinas and Pradell 2018).

With the Fatimid conquest of Egypt in $969 \mathrm{AD}$ and the foundation of Cairo as the dynasty capital, further technological changes occurred. In Type III-1, transparent yellow and green glazes are applied over an overall white tin-opacified glaze resulting in a decoration, similar in appearance to the earlier production of polychrome ceramics in Ifriqiya (Tunisia) where transparent yellow, green and brown glazes were applied over a white background. However, in Tunisia, the white background was produced by whitening the ceramic surface through the action of either the kiln atmosphere (Molera et al. 1998) or the application of salt water (Ownby and Griffiths 2017; Salinas and Pradell 2018) (Fig. 7), rather than using a white tin-opacified glaze.

Subsequently, in Type III-2 (FYG), the transparent yellow glaze is replaced by a lead antimonate opacified yellow glaze which, together with a green glaze, was spread over a substantial area of the overall tin-opacified white glaze. In contrast to the Type II-2 ceramics, lead antimonate was no longer used to opacify green glazes, but only the yellow glazes with antimony contents consistently higher than those in the Type II-2 yellow glazes (i.e, 0.8-1.5 $\mathrm{wt} \%$ as compared to $0.2-0.5 \mathrm{wt} \% \mathrm{Sb}_{2} \mathrm{O}_{3}$ ).

Consequently, it is suggested that the application of the coloured glazes over a white background in the both Type III-1 and Type III-2 ceramics was an influence from the earlier Fatimid polychrome productions in Ifriqiya (Tunisia) but in Egypt, a white tin opacified glaze was used to produce the white background. It is possible that, as in Ifriqiya, a transparent yellow glaze was used first in Type III-1, but that later lead antimonate opaque glaze was used in Type III-2.

Once the lead antimonate yellow technology was fully established in Fatimid Egypt, it appears to have started to spread back, together with the tin oxide white opacification, into North Africa. Therefore, with the Fatimid conquest of Egypt, there was a dynamic, contrary to what had originally been thought, in which the opaque glaze tradition spread from Egypt to Tunisia, and did not come from Tunisia to Egypt.

\subsection{Rediscovery of lead antimonate yellow}

As discussed by Matin et al. (2018), when a mixture of lead/tin calx and quartz with the composition of a very high lead glaze is fired to $950^{\circ} \mathrm{C}$, instead of $850^{\circ} \mathrm{C}$, a tin-oxide white glaze is produced. Therefore, firing of a lead stannate yellow glaze to too high a temperature could have resulted in the chance production, and hence discovery, of a tinoxide white glaze. In contrast, when a mixture of lead-tin calx, quartz, alkali and lime with the composition of a typical lead-alkali glaze are fired to only $850^{\circ} \mathrm{C}$, a white glaze is already produced, and therefore, in spite of the relationship between the technologies for the production of yellow and white opaque glazes, as noted above, there is little likelihood that firing a mixture of this latter composition could have resulted in the chance production of an opaque yellow glaze. As a result, once the technology for the 
production of lead stannate opaque yellow glaze had been lost, as seems probable in Egypt by 2 nd half of $9^{\text {th }}$ century, it would not readily have been rediscovered.

The alternative as a yellow opacifier is lead antimonate which was used to produce opaque yellow glass in Egypt and the Near East from about $1500 \mathrm{BC}$ until the $4^{\text {th }}$ century AD, when Roman glass producers switched to the use of lead stannate yellow, together with tin oxide in place of calcium antimonate previously used for the production of white glass. Subsequently, Islamic potters used tin-based opacifiers in the production of their opaque yellow and white glazes, most probably as a result of contact with Byzantine or Islamic glass producers. The question therefore arises as to how Islamic potters in Egypt rediscovered the yellow lead antimonate opacifier in the second half of the $9^{\text {th }}$ century.

In view of the gap in time from the $4^{\text {th }}$ to the second half $9^{\text {th }}$ century, it seems very unlikely that the Islamic potters re-discovered lead antimonate as a result of surviving written documentation or an oral tradition of its past use. Instead, one possibility is that in the second half of the 9th century in Egypt the Islamic potters discovered and used an antimony-containing source of lead in the production of their yellow glazes.

The use of galena and of stibnite $\left(\mathrm{Sb}_{2} \mathrm{~S}_{3}\right)$ as both cosmetics (kohl) and medicines for eye infection and to protect from the sun has been described since predynastic Egypt. The use of stibnite rather than galena is specifically indicated both as a cosmetic in Islamic times in the Sunan books by Al Nasa'i (829-915 CE), where it is said that one of the best kind of kohl you can use is ithmid (antimony) it brightens the vision; and makes the hair (eye lashes) grow (Al Nasa'i 2007), and as a medicine (Goitein 2015).

Both stibnite and galena appear as associated minerals in hydrothermal deposits, and from such deposits, lead and antimony oxides could be obtained. In the above discussion, we have shown that the rediscovery of lead antimonate as a yellow pigment is related to the production of the polychrome glazed wares (Group II) in which up to seven different coloured glazes were used: that is, transparent uncoloured and brown; opaque white and turquoise using tin oxide particles; and opaque yellow, amber and green using lead antimonate particles. Therefore, it is suggested that the potters experimented with various available minerals, including stibnite or a galena with stibnite impurities, with a view to increasing their available palette of colours, rather than from a specific desire to produce a yellow glaze. The result was the emergence of three opaque colours which included yellow, as well as amber and green. The fact that the Islamic potters used only lead antimonate yellow, in contrast to the Roman glassmakers who used lead antimonate yellow together with calcium antimonate white, supports the argument that lead antimonate yellow was rediscovered by experimenting with stibnite/galena minerals, rather than through the recovery of the Roman technological tradition.

\section{Conclusions}

The production of Islamic glazed ceramics was probably initiated in Egypt during the Umayyad and subsequent Abbasid rule between late $7^{\text {th }}$ and early $9^{\text {th }}$ centuries, with the production of opaque yellow glazes using lead stannate together with transparent green 
and brown glazes, the different coloured glazes being applied side by side over the ceramic surface (Watson 2014, Tite et al 2015). Tin-opacified glazed wares were therefore first produced in Egypt prior to their production in Abbasid Iraq. Subsequently, in the second half of the $9^{\text {th }}$ century, influences from Abbasid Iraq reached Egypt resulting mainly in the modification of the shape of Egyptian vessels. In terms of decoration, the main difference was that the yellow glazes, although having the same composition, were now transparent.

Then, again starting in the second half of the $9^{\text {th }}$ century, new workshops were established in the Fustat area, resulting in the production of new types of glazed ware, among which was a multi-coloured glazed ware, whose production involved the rediscovery of yellow lead antimonate as a glaze opacifier. In addition to its use in the production of opaque yellow glaze, lead antimonate were also added to opacify amber and green coloured glazes. At the same time, tin oxide began to be used in Egypt for the production of both opaque white and opaque turquoise glazes. As in the earlier productions, the different colours were applied side by side over the ceramic surface.

The Fatimid conquest of Egypt resulted in Fustat becoming a major pottery production centre. One type of glazed ware, involving the application of transparent yellow and green glazes over a white background, clearly incorporated influences from Ifriqiya (Tunisia), from where the Fatimids originated. However, in contrast to the Tunisian production, the white background in Egypt was produced using a tin oxide opacified white glaze. Yellow, became an important glaze colour during the Fatimid rule, with lead antimonate opacified yellow glaze being spread over a substantial area of the underlying tin-opacified white glaze. Subsequently, in the late $10^{\text {th }}$ to early $11^{\text {th }}$ centuries, white tin oxide and yellow lead antimonate opaque glazes were also used in ceramic production in Tunisia, and from there spread to other Mediterranean regions.

The rediscovery of the yellow lead antimonate opacifier appears to have been a local innovation of the Egyptian potters who were looking to produce a multi-coloured glazed tableware, and its use persisted in the region well after the establishment of new ruling dynasties, becoming essentially an Egyptian trade mark.

In conclusion, the interrelationships between the different regions and the establishment of new ruling dynasties in the area have been shown to be the main driving force for the innovation in ceramic shapes and decoration, and the materials and technologies used in their production.

\section{Acknowledgements}

Elena Salinas is funded by the Marie Skłodowska-Curie Actions call H2020-MSCA-IF2015 project IGATO. We are grateful to the funds received from Ministerio de Ciencia e Innovación (Spain) project MAT2016-N0748719-R and Generalitat de Catalunya project 2017-SGR-00042.

\section{References}


Adams, W.Y., 1986. The Ceramic Industries of Medieval Nubia I. University Press of Kentucky, Lexington.

Al Nasa'i, 2007, Sunan an Nasa'i, edited by Hâfuz Abû Tâhir Zubair 'Alî Za'hi. English translation by Nâsiruddin al-Khattâb. Vol 6. 48. Book of Adornment, chapter 28, 5116. Ed. Dar us Salam, Ryad.

Bailey, D.M., 1998. Excavations at el-Ashmunein V: Pottery, Lamps and Glass of the Late Roman and Early Arab Periods, London.

Baioumy, H.M., Ismael, I.S., 2014. Composition, origin and industrial suitability of the Aswan ball clays, Egypt. Applied Clay Science 102 202-212.

Ballet, P., Mahmoud, F., Vichy, M., Picon, M., 1991. Artisanat de la céramique dans l'Égypte Romaine tardive et Byzantine. Prospections d'Ateliers de poters de Minia à Assouan. Extrait des Cahiers de la Céramique Égyptienne 2 129-143.

Ben Amara, A., Schvoerer, M., Thierrin-Michael, G., Rammah, M., 2005. Distinction de céramiques glaçurées aghlabides ou fatimides (IXe- XIe siècles, Ifriqiya) par la mise en évidence de différences de texture au niveau de l'interface glaçure - terre cuite. ArchéoSciences 29 35-42.

Fehérvári, G., 2000. "Chapter 3: the Fatimid period in Egypt and North Africa (Late Tenth to Twelfth centuries)" in Ceramics of the Islamic world in the Tareq Rajab Museum. London-New York: 65-77.

Fehérvári, G., 2006. Kuwait excavations at Bahnasā /Oxyrhynchus (1985-1987): final report. A.H. Pincis, D. Zahem (eds.). Kuwait: Dār al-Athār al-Islāmīyah and KFAS.

François, V, Shaddoud, I., 2013. Nouvel atelier de potier d'époque abbasside au sud de Tell Abou Ali à Raqqa. al-Rāfidān XXXIV 21-79

Gayraud, R.P., Vallauri, L., 2017. Fustat II. Fouilles d'Is $\square$ abl 'Antar. Céramiques d'ensembles des $I X^{e}$ et $X^{e}$ siècles. Institut français d'archéologie orientale. Fouilles de l'Ifao 75/Institut d'Archéologie Orientale, Le Caire.

Gayraud, R.P, Treglia, J.C., 2016. "La céramique d'une maison omeyyade de Fustât Istabl'Antar (Le Caire, Égypte). Vaisselles de table. Céramique comunes et culinaire, jarres de stockage et amphores de la pièce P5 (première moitié du VIII ${ }^{\mathrm{e}} \mathrm{S}$.)", in Actas do X Congresso Internacional a Cerámica Medieval no Mediterrâneo. Silves: 51-55.

Goitein, S.D. 2015. Letters of Medieval Jewish Traders. Princeton.

Matin, M., Tite, M. and Watson, O., 2018. On the origins of tin-opacified ceramic glazes: New evidence from early Islamic Egypt, the Levant, Mesopotamia, Iran, and Central Asia. Journal of Archaeological Science 97 42-66

Molera, J., Pradell, T., Vendrell-Saz, M., 1998, The colours of Ca-rich ceramic pastes: origin and characterization. Applied Clay Science 13 187-202

Molina G., Odin, G.P., Pradell, T., Shortand, A.J. and Tite, M.S., 2014, Production technology and replication of lead antimonate yellow glass from New Kingdom Egypt and the Roman Empire. Journal of Archaeological Science 41 171-184

Monchamp, J., 2018. Céramiques des Murailles du Caire (fin Xe-début XVI ${ }^{e}$ S.). 2 Vols. 
Ownby, M.F., Giomi, E., Williams, G., 2017. Glazed wares from here and there: Petrographic analysis of the technological transfer of glazing knowledge. JAS: Reports 16 616-626.

Ownby, M.F., Griffiths, D., 2009. Issues of scum: technical analyses of Egyptian marl C to answer technological questions. Egypt and the Levant 19 229-239.

Rodziewicz, M., 1978. La céramique émaillée copte à Kôm el-Dikka. Etudes et Traveaux 10 337-45.

Salinas, E., Pradell, T., 2018. Primeros resultados del proyecto «La introducción del vidriado en al-Andalus: olas tecnológicas e influencias orientales $\gg$, a partir de análisis arqueométricos, in Arqueometría de los materiales cerámicos de época medieval en España, ed F. Grassi \& J.A. Quirós, Documentos de Arqueología Medieval 12 241-251.

Scanlon, G.T., 1993. "Fayyumi Pottery: a Long-Lived Misnomer in Egyptian Islamic Ceramics. Type I," in Alexandrian Studies in Memoriam Daoud Abdu Daoud ed. P.C. Reynolds, Société Archéologique d'Alexandrie 45, 295-330.

Scanlon, G.T., 1998. "Slip-Painted Early Lead Glazed Wares from Fustat: a Dilemna of Nomenclature," in Colloque international d'archéologie islamique ed. R.P. Gayraud, Textes arabes études islamiques 36 (Cairo, 1993), 21-54.

Sheehan, P., 2010. Babylon of Egypt: The Archaeology $f$ Old Cairo and the Origins of the City. American University in Cairo Press.

Shovelton, E., 2018. "Dish" in Discover Islamic Art, Museum With No Frontiers. http://www.discoverislamicart.org/database_item.php?id=object;ISL;uk;Mus01;47;en

Taxel, I., 2014. Luxury and common wares: socio-economic aspects of the distribution of glazed pottery in Early Islamic Palestine. Levant 46.1, 118-139.

Tite, M. S, Freestone, I.C., Mason, I., Molera, J., Vendrell, M., Wood, N., 1998. "Lead glazes in antiquity- Methods of production and reasons for use". Archaeometry. 40, 241 $-260$.

Tite, M. S., 2010. The Technology of Glaze Islamic Ceramics Using Data Collected by the Late Alexander Kaczmarczyk. Archaeometry 53(2) 329-339.

Tite, M., Watson, O., Pradell, T., Matin, M., Molina, G., Domoney, K., Bouquillon, A., 2015, Revisiting the beginnings of tin-opacified Islamic glazes. Journal of Archaeological Sciences 57 80-91.

Yousef, E.S., 1996. Sedimentological studies on the central Wadi Kalabsha kaolin deposits, Southwest of Aswan, Egypt. J.Min.Petr.Econ.Geol. 91 353-363.

Waksman, S.Y., Capelli, C., Cabella, R., 2017. “Annexe: Études en laboratoire de céramiques islamiques du Caire: 1'apport des fouilles recentes", in GAYRAUD, R.-P., VALLAURI, L., Fustat II. Fouilles d'Is $\square$ abl 'Antar. Céramiques d'ensembles des IXe et $X^{e}$ siècles. Institut français d'archéologie orientale. Fouilles de l'Ifao 75/Institut d'Archéologie Orientale, Le Caire, 383-414.

Watson, O., 2004. Ceramics from Islamic lands. London. 
Watson, O., 2014. Revisiting Samarra: the rise of the Islamic glazed pottery. Beiträge Zur Islamischen Kunst Und Archäologie. 4 125-144.

Whitcomb, D., 1989. Coptic glazed ceramics from the excavations at Aqaba, Jordan. $J$. Am. Res. Centre Egypt 26 167-182.

Williams, G., 2013. "Fayyumi" Ware: Variations, Imitations, and Importations of an Early Islamic Glazed Ceramic Type. Thesis (unpublished work).

Williams, G., 2015. "Another View from the Edge: Medieval Pottery from the South of Egypt" (Poster Session) at the $11^{\text {th }}$ Colloquium of the Ernst Herzfeld-Society, Bamberg. 


\section{Figure captions}

Figure 1. Glazed sherds from Fustat selected from the Kaczmarczyk collection (Tite 2010). Pottery I-1 redrawn from Scanlon (1989), I-2, II-1, II-2, III-1 redrawn from Gayraud \& Vallaury (2017) and III-2 drawn by the authors.

Figure 2. Comparison between the chemical compositions (wt\% normalised to $100 \%$ ) of the Egyptian glazed ware Groups. A) $\mathrm{FeO}$ vs. $\mathrm{Al}_{2} \mathrm{O}_{3}$ and $\mathrm{CaO}$ vs. $\mathrm{Al}_{2} \mathrm{O}_{3}$ for the ceramic pastes, and $\mathrm{B}) \mathrm{PbO}$ vs. $\mathrm{Al}_{2} \mathrm{O}_{3}$ and $\left(\mathrm{Na}_{2} \mathrm{O}+\mathrm{K}_{2} \mathrm{O}\right)$ vs. $\mathrm{Al}_{2} \mathrm{O}_{3}$ for the glazes.

Figure 3. Optical Microscopy images of A) kaolinitic clay fabric (Aswan) (ALX203) and B) calcareous clay fabric (ALX142)

Figure 4. Group I yellow glazes. A) Dark field Optical image and B) SEM-BSE image for the opaque yellow glaze applied to ALX202 (Type I-1) with lead stannate particles appearing white in the latter image. C) Dark field Optical image and D) SEM-BSE image for the transparent yellow glaze applied to ALX203 (Type I-2) with no particles visible in the latter.

Figure 5. Type II-2 glazes. A) Dark field and B) Bright field Optical images for ALX65 showing a brown glaze (left) and a white glaze (right) applied side by side. Tin oxide particles (lighter grey) are visible in the white glaze but no particles are visible in the brown glaze.

C) Dark field and D) Bright field Optical images of the amber glaze applied to ALX146, and at higher magnification, E) Bright field Optical image (for marked rectangle in D) and F) SEM-BSE image showing well crystallised lead antimonate particles with polyhedral shapes (lighter grey to white).

Dark field Optical images for ALX154 showing G) turquoise glaze containing tin oxide particles (lighter grey), and H) green glaze containing lead antimonate particles (lighter grey).

Figure 6. Type III-2 glazes applied to ALX135. A) General optical image showing the yellow and green glazes applied over a white glaze.

B) Dark field and C) Bright field Optical images for the yellow over white glaze, together with SEM-BSE images (D and E) showing the presence of small wellcrystallised lead antimonate particles (white arrows) in the yellow layer. E) shows marked rectangular area in D) at higher magnification.

F) Dark field and G) Bright field Optical images for green glaze over, as revealed in $\mathrm{H}$ ) SEM-BSE image, narrow layers of both yellow glaze containing small well-crystallised lead antimonate particles (white arrows), and white glaze containing cassiterite particles (black arrows).

Figure 7. A) Ceramic sherd from Tunisia ( $9^{\text {th }}$ century) found at the excavation of the Islamic settlement of Madinat Ilbira (Spain). B) and C) Optical images of cross sections through the sherd showing the whitened surface below a transparent lead glaze. 
Figure 1.
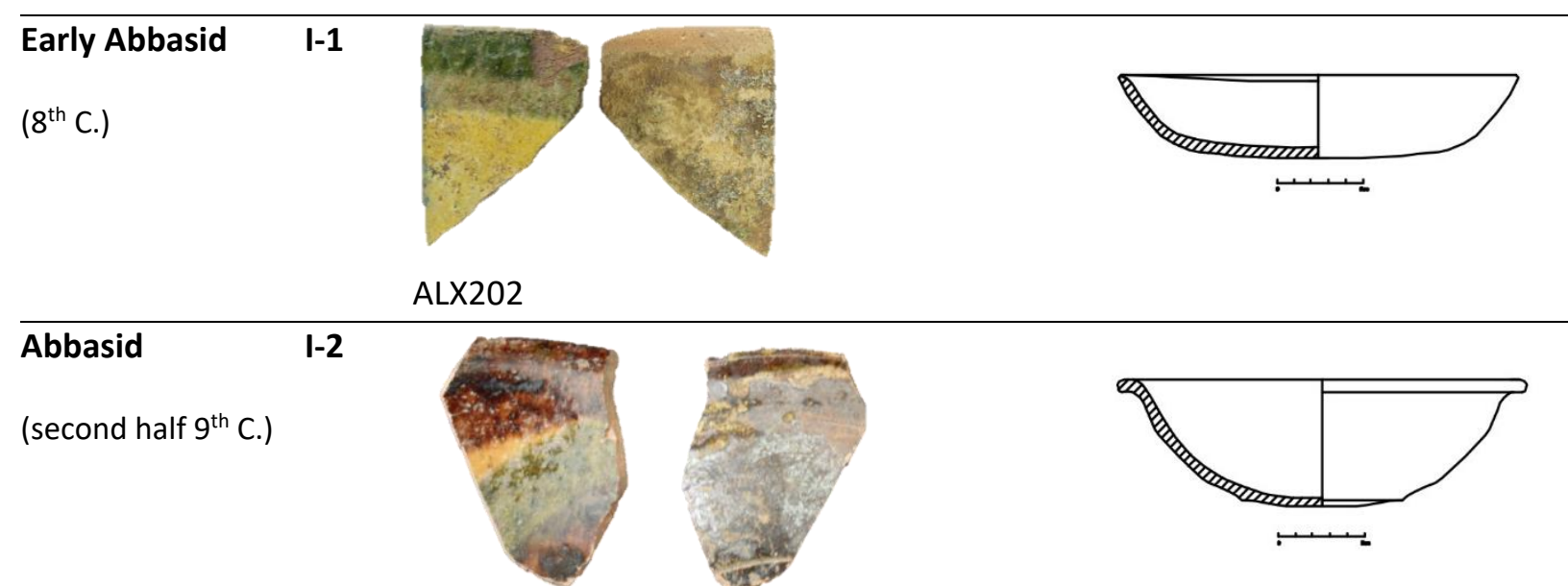

ALX203

(second half $9^{\text {th }}$ C.)

\begin{tabular}{lll}
\hline Abbasid & $\mathrm{II-2}$ \\
$\left(10^{\text {th }} \mathrm{C}.\right)$ &
\end{tabular}

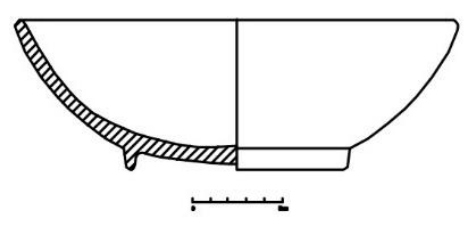

ALX65

\section{Fatimid}

(late $10^{\text {th }}-11^{\text {th }} \mathrm{C}$.)

III-1

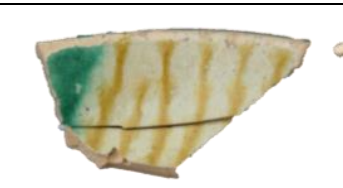

ALX142

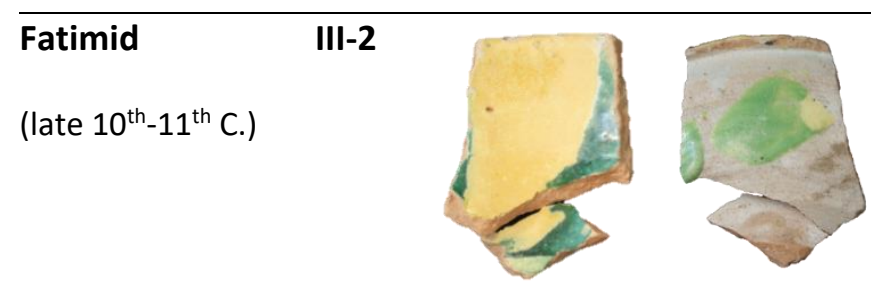

ALX135 
Figure 2.
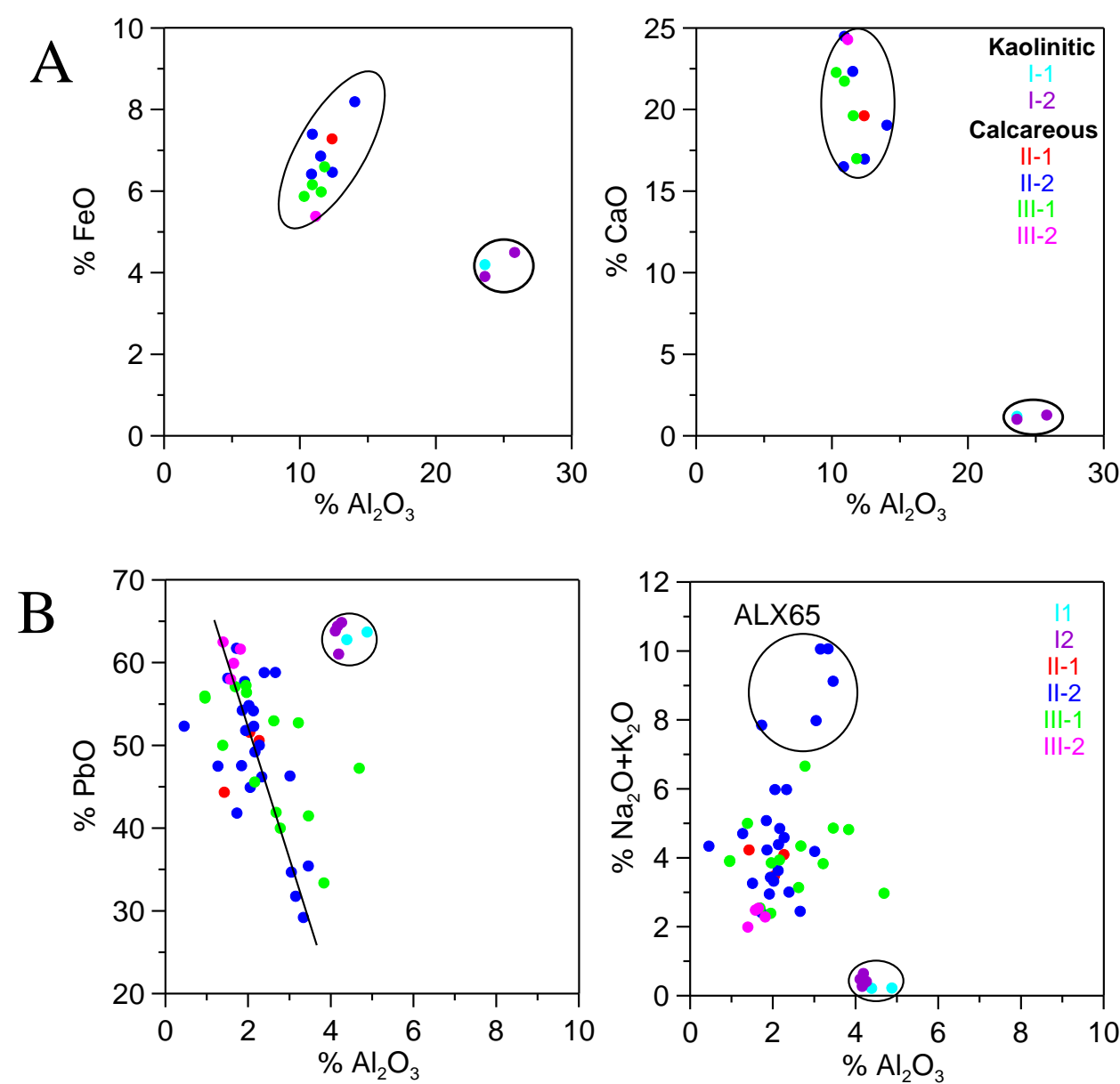
Figure 3.
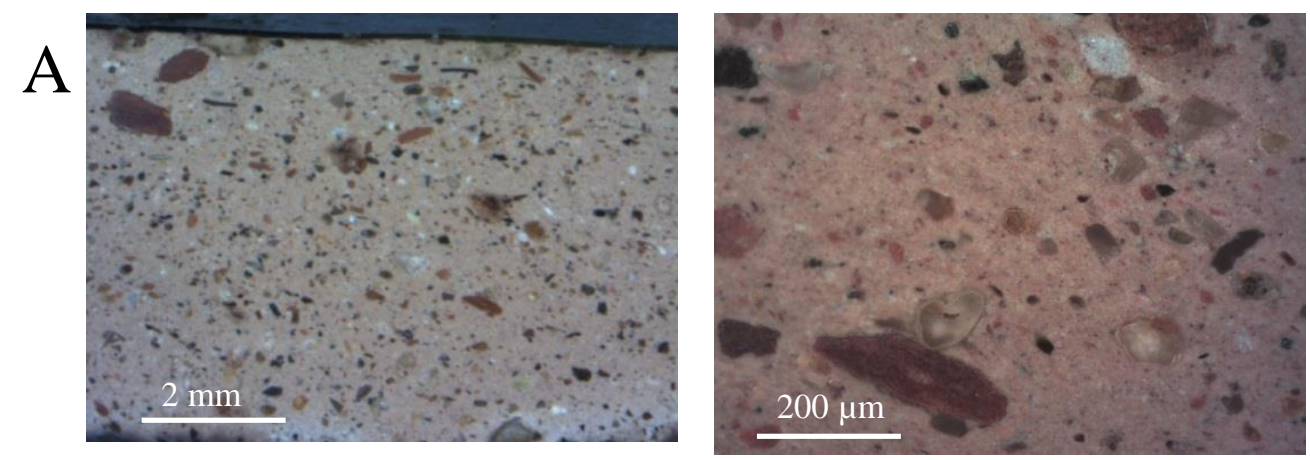

B
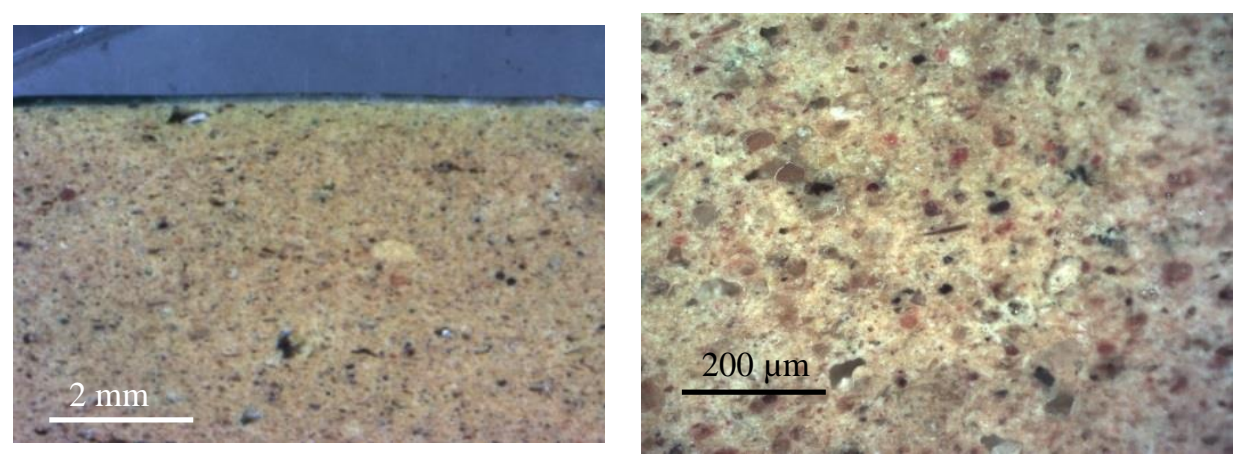
Figure 4.
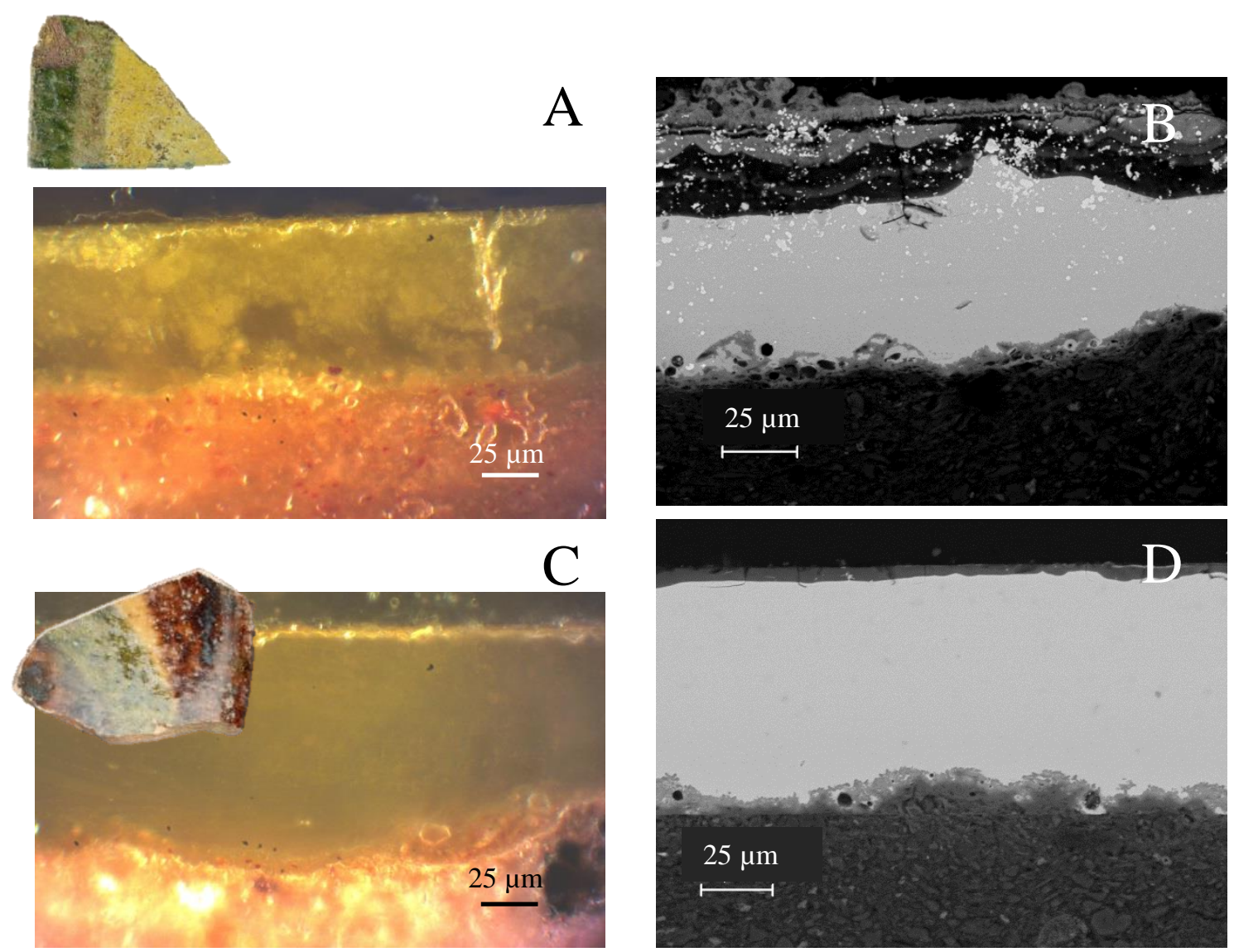
Figure 5.
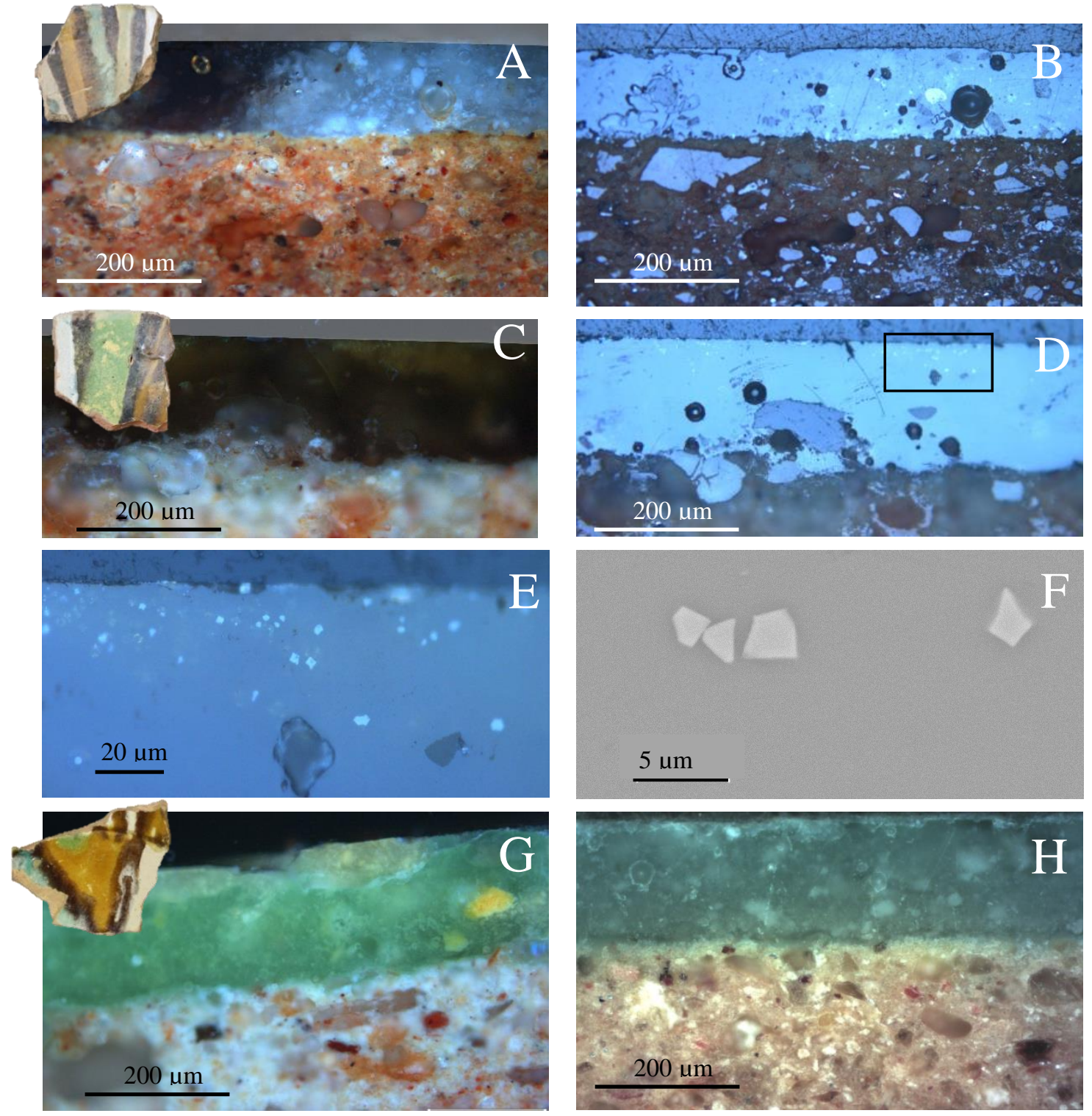
Figure 6.
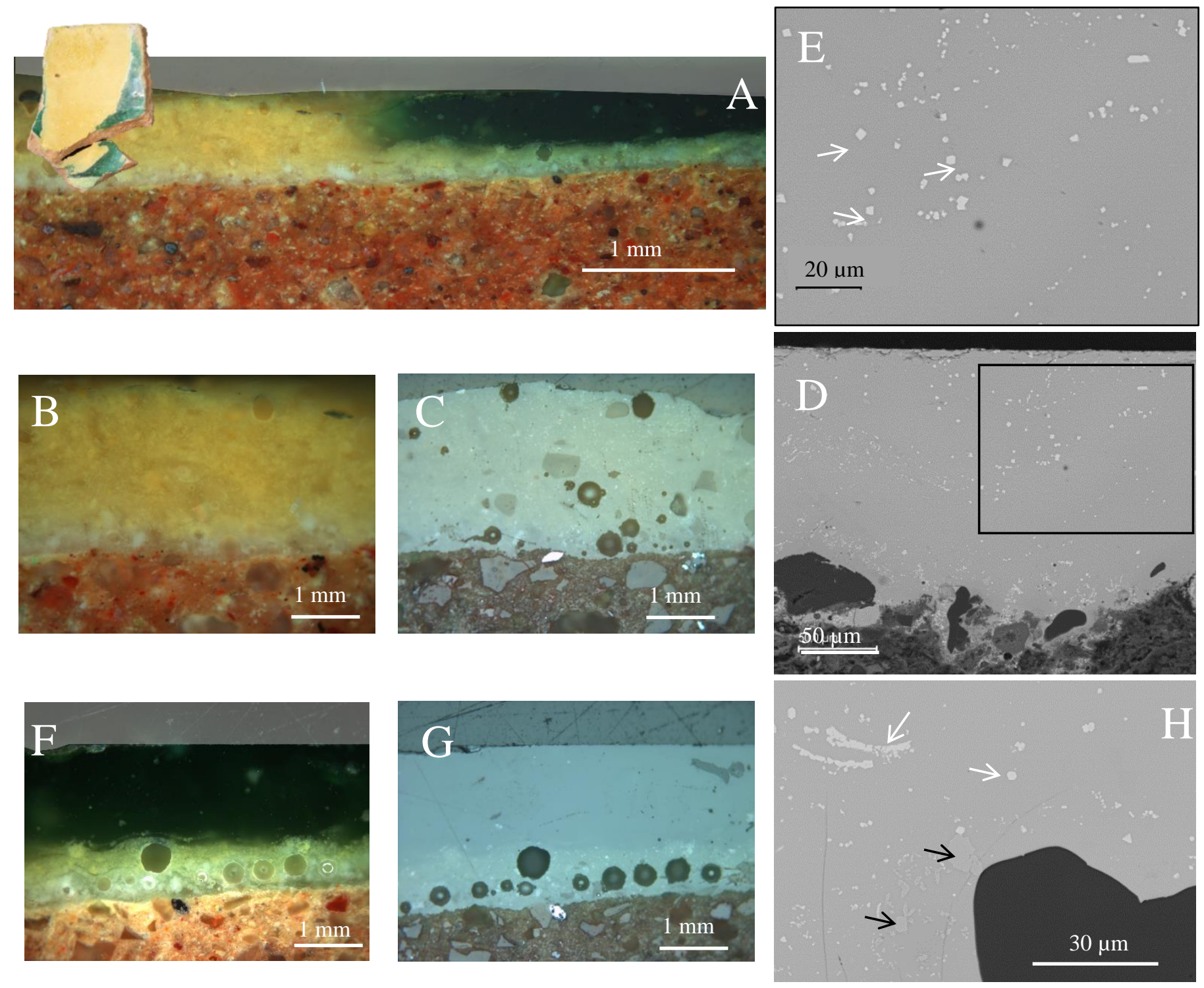
Figure 7

(A)

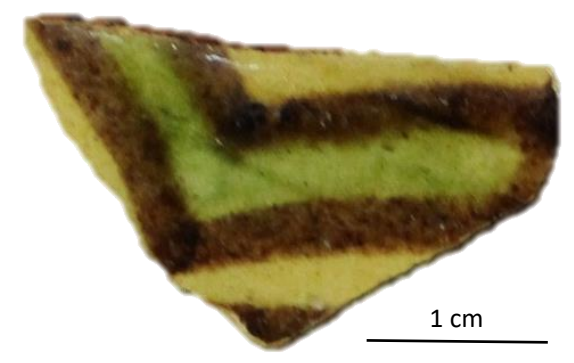

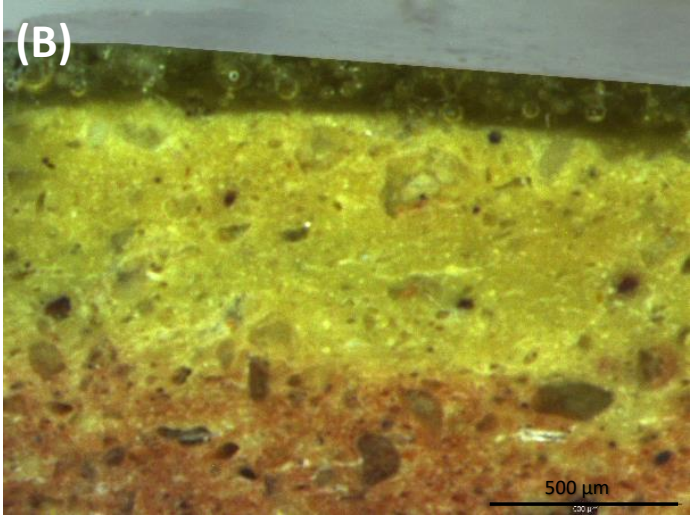


Table 1. Groups of Islamic Egyptian glazed ware

\begin{tabular}{|c|c|c|c|}
\hline Type & Description & Date & Samples \\
\hline \multicolumn{4}{|c|}{ Group I Kaolinitic Glazed Ware (KGW) } \\
\hline $\mathrm{I}-1$ & Coptic Glazed Ware (CGW) & late $7^{\text {th }}$ - early $9^{\text {th }} \mathrm{C}$ & ALX202 \\
\hline $\mathrm{I}-2$ & Transition toward Type II - 1 & second half $9^{\text {th }} \mathrm{C}$ & ALX203, ALX205 \\
\hline \multicolumn{4}{|c|}{ Group II Polychrome Glazed Ware (PGW) } \\
\hline$\|-1$ & Early Fayyumi ware & second half $9^{\text {th }} \mathrm{C}$ & ALX63 \\
\hline II-2 & Fayyumi type I ware & $10^{\text {th }} \mathrm{C}$ & $\begin{array}{c}\text { ALX51, ALX65, ALX146, } \\
\text { ALX152, ALX154 }\end{array}$ \\
\hline \multicolumn{4}{|c|}{ Group III Fatimid Polychrome Glazed Ware (FGW) } \\
\hline III-1 & $\begin{array}{l}\text { Polychrome opaque } \\
\text { white glazed ware }\end{array}$ & late $10^{\text {th }}-11^{\text {th }} \mathrm{C}$ & ALX142 \\
\hline III-2 & Fatimid Yellow Glazed Ware (FYG) & late $10^{\text {th }}-11^{\text {th }} \mathrm{C}$ & $\begin{array}{l}\text { ALX231, ALX66, } \\
\text { ALX342, ALX135 }\end{array}$ \\
\hline
\end{tabular}


Table 2. Ceramic pastes analysis (wt\% normalised to 100\%).

\begin{tabular}{|c|c|c|c|c|c|c|c|c|c|c|c|}
\hline & & & $\mathrm{Na}_{2} \mathrm{O}$ & $\mathrm{MgO}$ & $\mathrm{Al}_{2} \mathrm{O}_{3}$ & $\mathrm{SiO}_{2}$ & $\mathrm{~K}_{2} \mathrm{O}$ & $\mathrm{CaO}$ & $\mathrm{TiO}_{2}$ & $\mathrm{FeO}$ & $\mathrm{PbO}$ \\
\hline \multirow{3}{*}{$\begin{array}{l}\text { Group I } \\
\text { KGW }\end{array}$} & $\mathrm{I}-1$ & ALX202 & 0.7 & 0.7 & 23.6 & 66.4 & 1.4 & 1.2 & 1.9 & 4.2 & bd \\
\hline & \multirow{2}{*}{$\mathrm{I}-2$} & ALX203 & 1.1 & 0.8 & 25.8 & 62.5 & 1.6 & 1.3 & 1.7 & 4.5 & 0.7 \\
\hline & & ALX205 & 0.5 & 0.7 & 23.6 & 67.1 & 1.1 & 1.0 & 1.5 & 3.9 & \\
\hline \multirow{6}{*}{$\begin{array}{l}\text { Group II } \\
\text { PGW }\end{array}$} & $\mathrm{II}-1$ & ALX63 & 1.2 & 3.5 & 12.4 & 52.3 & 1.3 & 19.6 & 0.9 & 7.3 & 1.3 \\
\hline & \multirow{5}{*}{ II-2 } & ALX51 & 2.1 & 4.0 & 14.0 & 48.3 & 1.7 & 19.1 & 1.1 & 8.2 & \\
\hline & & ALX65 & 1.8 & 2.8 & 12.4 & 53.5 & 2.5 & 17.0 & 0.8 & 6.5 & \\
\hline & & ALX146 & 1.7 & 2.8 & 10.9 & 48.2 & 2.0 & 24.5 & 1.1 & 7.4 & \\
\hline & & ALX152 & 1.5 & 2.4 & 10.8 & 53.7 & 1.5 & 16.5 & 0.8 & 6.4 & 1.0 \\
\hline & & ALX154 & 1.5 & 3.5 & 11.5 & 50.3 & 1.3 & 22.3 & 0.8 & 6.9 & \\
\hline \multirow{5}{*}{$\begin{array}{c}\text { Group III } \\
\text { FGW }\end{array}$} & III-1 & ALX142 & 1.6 & 4.1 & 11.1 & 49.6 & 1.5 & 24.3 & 1.0 & 5.4 & \\
\hline & \multirow{4}{*}{$\mid I I-2$} & ALX231 & 2.2 & 3.4 & 10.3 & 49.6 & 2.4 & 22.3 & 0.9 & 5.9 & \\
\hline & & ALX66 & 1.4 & 2.7 & 11.8 & 57.1 & 1.6 & 17.0 & 1.0 & 6.6 & 0.6 \\
\hline & & ALX135 & 1.5 & 3.4 & 11.6 & 53.1 & 1.7 & 19.6 & 1.0 & 6.0 & \\
\hline & & ALX342 & 1.3 & 3.1 & 10.9 & 52.7 & 1.3 & 21.7 & 0.9 & 6.2 & \\
\hline
\end{tabular}

Table 3. Glaze analysis of Group I (KGW) (wt\% normalised to 100\%). D: Decorated side; G:

Green; Y: Yellow; Y/G: yellow-green. B: Brown

sample side colour $\mathrm{Na}_{2} \mathrm{O} \quad \mathrm{MgO} \quad \mathrm{Al}_{2} \mathrm{O}_{3} \quad \mathrm{SiO}_{2} \quad \mathrm{~K}_{2} \mathrm{O} \quad \mathrm{CaO} \quad \mathrm{TiO}_{2} \mathrm{MnO} \quad \mathrm{FeO} \quad \mathrm{CuO} \quad \mathrm{ZnO} \quad \mathrm{SnO}_{2} \quad \mathrm{Sb}_{2} \mathrm{O}_{3} \quad \mathrm{PbO}$

\begin{tabular}{|c|c|c|c|c|c|c|c|c|c|c|c|c|c|c|c|c|}
\hline \multirow{2}{*}{$\begin{array}{c}\mathrm{I}-1 \\
\text { (CGW) }\end{array}$} & \multirow{2}{*}{ ALX202 } & \multirow{2}{*}{ D } & G & 0.0 & 0.3 & 4.2 & 28.0 & 0.2 & 2.3 & \multicolumn{2}{|l|}{0.4} & 1.0 & 3.5 & 0.3 & 0.1 & 59.7 \\
\hline & & & $Y$ & 0.1 & 0.1 & 4.8 & 30.3 & 0.2 & 0.1 & & & 0.8 & & & 1.7 & 62.1 \\
\hline \multirow{4}{*}{$1-2$} & \multirow{3}{*}{ ALX203 } & \multirow{3}{*}{ D } & $Y$ & 0.2 & 0.2 & 4.1 & 29.1 & 0.1 & 0.5 & 0.5 & & 0.9 & & & 1.6 & 62.8 \\
\hline & & & G & 0.4 & 0.2 & 4.0 & 29.8 & 0.2 & 2.1 & 0.4 & & 1.7 & 1.5 & 0.9 & 0.6 & 58.2 \\
\hline & & & B & 0.3 & 0.0 & 4.0 & 29.8 & 0.2 & 0.6 & 0.4 & 0.8 & 0.7 & & & 0.9 & 62.3 \\
\hline & ALX205 & D & $\mathrm{Y} / \mathrm{G}$ & 0.3 & 0.3 & 4.1 & 26.7 & 0.1 & 2.1 & 0.4 & & 1.5 & 0.8 & & 0.8 & 62.8 \\
\hline
\end{tabular}


Table 4. Glaze analysis of Group II (PGW) (wt\% normalised to 100\%). U: Undecorated side; D: Decorated side; A: Amber; G: Green; W: White; Y: Yellow; Y/G: yellow-green. B: Brown; Tu: Turquoise; Tr: Transparent

\begin{tabular}{|c|c|c|c|c|c|c|c|c|c|c|c|c|c|c|c|c|c|}
\hline & sample & side & colour & $\mathrm{Na}_{2} \mathrm{O}$ & $\mathrm{MgO}$ & $\mathrm{Al}_{2} \mathrm{O}_{3}$ & $\mathrm{SiO}_{2}$ & $\mathrm{~K} 2 \mathrm{O}$ & $\mathrm{CaO}$ & $\mathrm{TiO}_{2}$ & $\mathrm{MnO}$ & $\mathrm{FeO}$ & $\mathrm{CuO}$ & $\mathrm{ZnO}$ & $\mathrm{SnO}_{2}$ & $\mathrm{Sb}_{2} \mathrm{O}_{3}$ & $\mathrm{PbO}$ \\
\hline \multirow{3}{*}{ II-1 } & \multirow{3}{*}{ ALX63 } & U & G & 2.3 & 0.7 & 2.2 & 37.6 & 1.7 & 3.5 & & & 1.1 & 1.2 & & & 0.6 & 49.2 \\
\hline & & \multirow{2}{*}{ D } & G & 1.8 & 0.3 & 1.9 & 37.6 & 1.5 & 2.8 & & & 0.6 & 2.5 & & 1.9 & 0.2 & 48.9 \\
\hline & & & W & 2.0 & 0.2 & 1.3 & 44.4 & 2.0 & 2.8 & & & 0.5 & 1.2 & & 3.3 & & 42.0 \\
\hline \multirow{23}{*}{ II-2 } & \multirow{4}{*}{ ALX51 } & U & $\mathrm{Y} / \mathrm{G}$ & 2.8 & 0.3 & 1.8 & 36.3 & 1.3 & 1.4 & 0.3 & & 1.8 & 0.1 & & 0.3 & 0.3 & 52.4 \\
\hline & & \multirow{3}{*}{ D } & $Y$ & 2.7 & 0.4 & 2.1 & 39.0 & 2.0 & 2.9 & 0.5 & & 2.3 & 0.1 & & & 0.2 & 48.0 \\
\hline & & & B & 2.6 & 0.3 & 2.2 & 38.2 & 1.8 & 3.0 & & 1.6 & 0.9 & 0.3 & 0.3 & 0.0 & 0.3 & 48.1 \\
\hline & & & $B / W$ & 2.7 & 0.6 & 1.2 & 40.9 & 1.7 & 2.4 & 0.2 & 0.7 & 0.6 & 0.3 & 0.2 & 3.5 & & 45.0 \\
\hline & \multirow{6}{*}{ ALX65 } & \multirow{5}{*}{ D } & Tu & 5.1 & 0.6 & 1.6 & 41.1 & 2.0 & 2.0 & 0.2 & 0.3 & 0.9 & 1.6 & & 5.7 & & 37.8 \\
\hline & & & B & 6.4 & 1.2 & 3.2 & 49.8 & 3.1 & 2.5 & 0.7 & 2.7 & 1.3 & 0.4 & & 0.2 & & 27.6 \\
\hline & & & $\mathrm{Y} / \mathrm{G}$ & 3.5 & 0.6 & 2.3 & 39.4 & 2.3 & 3.5 & 0.8 & & 1.3 & 0.2 & & 0.0 & 0.5 & 44.9 \\
\hline & & & w & 5.8 & 0.8 & 3.2 & 46.3 & 2.8 & 1.7 & & 0.5 & 1.2 & 0.1 & & 3.2 & 0.1 & 33.2 \\
\hline & & & $\mathrm{B} / \mathrm{Tu}$ & 6.3 & 1.3 & 2.9 & 47.5 & 3.0 & 1.9 & 0.5 & 4.1 & 1.1 & 0.6 & & & & 29.6 \\
\hline & & U & $\operatorname{Tr}$ & 4.2 & 1.1 & 3.0 & 47.7 & 3.5 & 3.3 & 0.6 & 0.1 & 1.6 & 0.26 & & & & 33.6 \\
\hline & \multirow{5}{*}{ ALX146 } & & W & 3.1 & 0.2 & 1.7 & 40.3 & 1.6 & 1.4 & 0.2 & & 1.2 & 1.1 & & 5.4 & & 44.0 \\
\hline & & & $B / A$ & 1.9 & 0.1 & 2.3 & 32.9 & 1.0 & 1.2 & 0.3 & 0.6 & 2.4 & & & & 1.0 & 56.7 \\
\hline & & & B & 1.4 & 0.4 & 2.6 & 32.3 & 1.0 & 2.2 & 0.4 & 1.8 & 1.0 & 0.8 & & & & 57.6 \\
\hline & & & $\mathrm{G} / \mathrm{Y}$ & 1.7 & 0.1 & 1.7 & 32.3 & 0.7 & 1.2 & 0.2 & & 0.7 & 1.3 & & 0.3 & 0.8 & 61.2 \\
\hline & & U & $\operatorname{Tr}$ & 1.5 & 0.2 & 2 & 37.1 & 1.8 & 1.9 & 0.3 & 0.1 & 1.3 & 0.1 & & & & 54.4 \\
\hline & \multirow{4}{*}{ ALX152 } & \multirow{3}{*}{ D } & W & 3.4 & 0.1 & 1.9 & 42.4 & 2.1 & 0.7 & 0.4 & & 0.3 & & & 6.2 & & 41.6 \\
\hline & & & G & 1.7 & 0.3 & 1.5 & 34.2 & 1.5 & 1.6 & & & 0.5 & 0.9 & & 0.3 & 0.9 & 56.7 \\
\hline & & & B & 2.1 & 0.2 & 2.1 & 37.5 & 2.2 & 2.1 & 0.2 & 1.9 & 0.5 & 0.1 & & & & 50.9 \\
\hline & & U & $\mathrm{Tr}$ & 1.5 & 0.4 & 3.0 & 43.1 & 2.6 & 2.3 & & & 1.1 & & & 0.2 & 0.1 & 45.6 \\
\hline & \multirow{4}{*}{ ALX154 } & \multirow{3}{*}{ D } & Tu & 2.2 & 0.2 & 0.4 & 36.9 & 1.8 & 2.5 & & & 0.4 & 0.7 & 0.3 & 5.7 & & 48.3 \\
\hline & & & B & 1.4 & 0.3 & 1.9 & 33.3 & 1.4 & 2.7 & 0.3 & 1.5 & 0.9 & & & & & 56.3 \\
\hline & & & A & 1.5 & 0.3 & 2.0 & 34.7 & 1.9 & 2.9 & 0.2 & 0.2 & 2.8 & & & 0.2 & 1.7 & 51.6 \\
\hline & & $\mathrm{M}$ & $\operatorname{Tr}$ & 1.3 & 0.2 & 1.9 & 39.4 & 2.1 & 2.2 & 0.3 & & 1.5 & & & & & 50.9 \\
\hline
\end{tabular}


Table 5. Glaze analysis of Group III (FGW) (wt\% normalised to 100\%). U: Undecorated side;

D: Decorated side; A: Amber; G: Green; W: White; Y: Yellow. Tr: Transparent

\begin{tabular}{|c|c|c|c|c|c|c|c|c|c|c|c|c|c|c|c|c|c|}
\hline & sample & side & colour & $\mathrm{Na}_{2} \mathrm{O}$ & $\mathrm{MgO}$ & $\mathrm{Al}_{2} \mathrm{O}_{3}$ & $\mathrm{SiO}_{2}$ & $\mathrm{~K} 2 \mathrm{O}$ & $\mathrm{CaO}$ & $\mathrm{TiO}_{2}$ & $\mathrm{MnO}$ & $\mathrm{FeO}$ & $\mathrm{CuO}$ & $\mathrm{ZnO}$ & $\mathrm{SnO}_{2}$ & $\mathrm{Sb}_{2} \mathrm{O}_{3}$ & $\mathrm{PbO}$ \\
\hline \multirow{4}{*}{ III-I } & \multirow{4}{*}{ ALX142 } & \multirow{2}{*}{$\begin{array}{c}D \\
\text { (out) }\end{array}$} & G & 0.7 & 0.5 & 1.7 & 30.4 & 1.5 & 1.7 & & & 0.7 & 1.9 & & 2.1 & & 58.7 \\
\hline & & & W & 0.9 & 0.5 & 1.6 & 32.5 & 1.5 & 1.7 & & & 0.6 & & & 2.7 & & 58.0 \\
\hline & & \multirow{2}{*}{$\begin{array}{l}\text { D } \\
\text { (in) }\end{array}$} & W & 1.0 & 0.4 & 1.5 & 34.3 & 1.4 & 1.7 & & & 0.7 & & & 3.4 & & 55.6 \\
\hline & & & Y & 0.9 & 0.5 & 1.4 & 30.5 & 1.0 & 2.1 & & & 1.9 & & & 1.0 & & 60.7 \\
\hline \multirow{14}{*}{$\begin{array}{l}\text { III-2 } \\
\text { (FYG) }\end{array}$} & \multirow{3}{*}{ ALX231 } & \multirow{2}{*}{$D$} & Y & 1.5 & 0.3 & 1.6 & 35.7 & 1.0 & 0.7 & \multirow[t]{2}{*}{0.4} & & 1.9 & 0.1 & & 0.6 & 1.4 & 54.6 \\
\hline & & & G & 1.3 & 0.2 & 1.8 & 34.6 & 1.0 & 1.2 & & & 2.3 & 2.8 & & & 0.4 & 53.7 \\
\hline & & $U$ & $\operatorname{Tr}$ & 1.0 & 0.9 & 4.6 & 39.9 & 2.0 & 3.5 & 0.4 & & 1.5 & 0.1 & & & & 46.7 \\
\hline & \multirow{3}{*}{ ALX66 } & \multirow{2}{*}{$\mathrm{D}$} & Y & 1.6 & 0.2 & 3.1 & 36.6 & 2.1 & 2.0 & & 0.1 & 2.3 & bd & bd & 0.3 & 0.9 & 50.9 \\
\hline & & & G & 1.3 & 0.4 & 2.5 & 37.3 & 1.7 & 1.7 & & 0.1 & 1.6 & 1.4 & 0.6 & 0.2 & 0.6 & 50.6 \\
\hline & & $U$ & $\operatorname{Tr}$ & 1.5 & 0.4 & 3.4 & 45.7 & 3.2 & 2.6 & 0.3 & 0.1 & 1.4 & 0.2 & & & 0.3 & 40.5 \\
\hline & \multirow{3}{*}{ ALX342 } & \multirow{2}{*}{$D$} & Y & 2.0 & 0.1 & 2.0 & 44.2 & 1.7 & 1.2 & & & 1.5 & & & 3.2 & 0.8 & 42.9 \\
\hline & & & G & 2.1 & 0.2 & 2.5 & 45.5 & 1.9 & 1.8 & 0.2 & & 0.9 & 0.4 & & 5.1 & & 39.1 \\
\hline & & $U$ & W & 1.5 & 0.5 & 3.5 & 47.6 & 2.8 & 4.1 & 0.6 & & 1.6 & & & 7.3 & & 30.4 \\
\hline & \multirow{5}{*}{ ALX135 } & \multirow{4}{*}{$\mathrm{D}$} & Y & 2.6 & 0.2 & 0.9 & 36.3 & 1.0 & 0.3 & & & 1.7 & & & 2.6 & 1.1 & 52.5 \\
\hline & & & G & 2.8 & 0.5 & 1.9 & 33.5 & 0.9 & 1.9 & 0.3 & & 1.0 & 2.7 & & & & 54.0 \\
\hline & & & $\mathrm{W}$ below $\mathrm{Y}$ & 2.7 & 0.2 & 0.9 & 36.0 & 1.0 & 0.1 & & & 1.7 & 0.1 & & 5.2 & & 51.3 \\
\hline & & & Y/W below $\mathrm{G}$ & 2.9 & 0.2 & 1.3 & 39.4 & 1.8 & 1.1 & 0.1 & & 1.6 & 1.5 & & 1.1 & 1.5 & 46.9 \\
\hline & & $\mathrm{D}$ & W & 2.4 & 0.1 & 2.6 & 45.1 & 3.8 & 1.6 & 0.3 & & 0.6 & 0.1 & & 5.5 & & 37.3 \\
\hline
\end{tabular}

